NATIONAL LABORATORY

MANAGED BY UT-BATTELLE

FOR THE DEPARTMENT OF ENERGY

\title{
Energy, Carbon-emission and \\ Financial Savings from Thermostat Control
}

\section{May 2013}

Prepared by

T.J. Blasing

Dana Schroeder

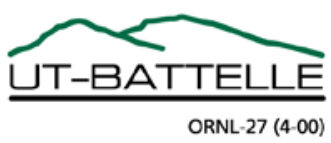




\title{
DOCUMENT AVAILABILITY
}

Reports produced after January 1, 1996, are generally available free via the U.S. Department of Energy (DOE) Information Bridge.

Web site http://www.osti.gov/bridge

Reports produced before January 1, 1996, may be purchased by members of the public from the following source.

\author{
National Technical Information Service \\ 5285 Port Royal Road \\ Springfield, VA 22161 \\ Telephone 703-605-6000 (1-800-553-6847) \\ TDD 703-487-4639 \\ Fax 703-605-6900 \\ E-mail info@ntis.fedworld.gov \\ Web site http://www.ntis.gov/support/ordernowabout.htm
}

Reports are available to DOE employees, DOE contractors, Energy Technology Data

Exchange (ETDE) representatives, and International Nuclear Information System (INIS)

representatives from the following source.

Office of Scientific and Technical Information

P.O. Box 62

Oak Ridge, TN 37831

Telephone 865-576-8401

Fax 865-576-5728

E-mail reports@adonis.osti.gov

Web site http://www.osti.gov/contact.html

This report was prepared as an account of work sponsored by an agency of the United States Government. Neither the United States Government nor any agency thereof, nor any of their employees, makes any warranty, express or implied, or assumes any legal liability or responsibility for the accuracy, completeness, or usefulness of any information, apparatus, product, or process disclosed, or represents that its use would not infringe privately owned rights. Reference herein to any specific commercial product, process, or service by trade name, trademark, manufacturer, or otherwise, does not necessarily constitute or imply its endorsement, recommendation, or favoring by the United States Government or any agency thereof. The views and opinions of authors expressed herein do not necessarily state or reflect those of the United States Government or any agency thereof. 
ORNL/TM-2013/55

\title{
ENERGY, CARBON-EMISSION AND FINANCIAL SAVINGS FROM THERMOSTAT CONTROL
}

\author{
T.J. Blasing ${ }^{1}$ \\ Dana Schroeder ${ }^{2}$ \\ ${ }^{1}$ Environmental Sciences Division \\ Oak Ridge National Laboratory \\ ${ }^{2}$ Environmental Economics and Management \\ University of Georgia
}

May 2013

Prepared by:

OAK RIDGE NATIONAL LABORATORY

Environmental Sciences Division

Climate Change Science Institute

Oak Ridge, Tennessee 37831

Managed by

UT BATTELLE, LLC

for the

U.S. DEPARTMENT OF ENERGY

under contract No. DE-AC05-00OR22725 
(THIS PAGE LEFT BLANK INTENTIONALLY) 


\section{CONTENTS}

Page

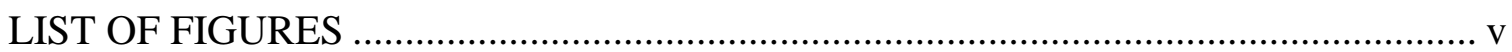

LIST OF TABLES ...............................................................................................

LIST OF ACRONYMS …...................................................................................... vii

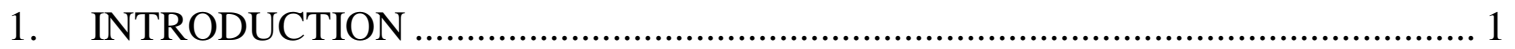

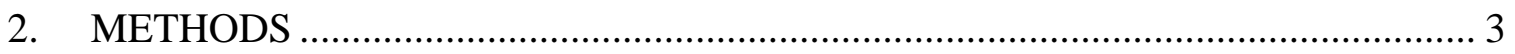

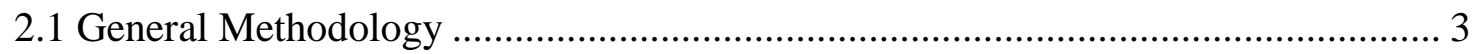

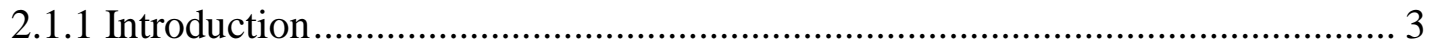

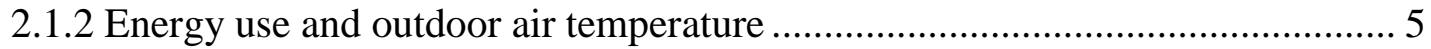

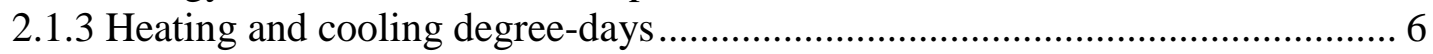

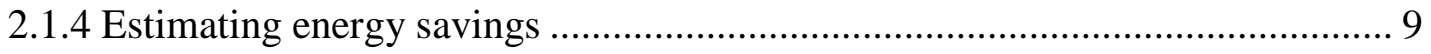

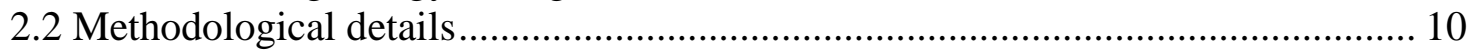

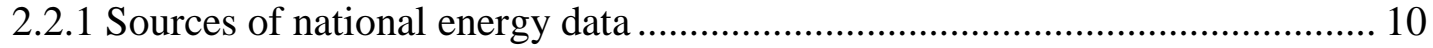

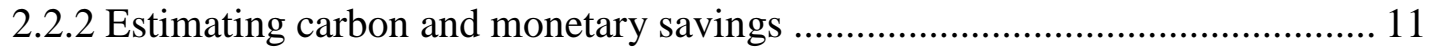

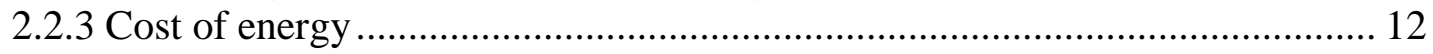

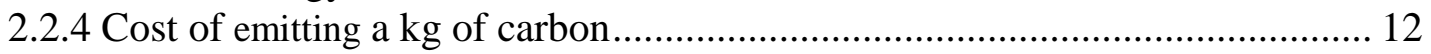

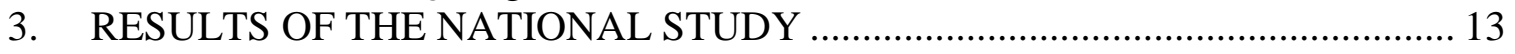

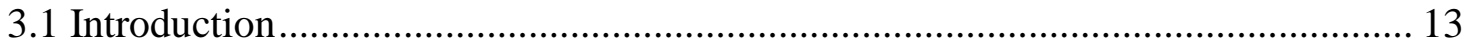

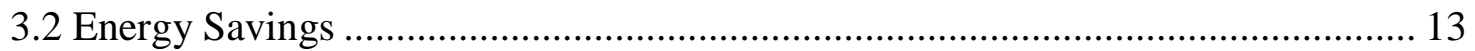

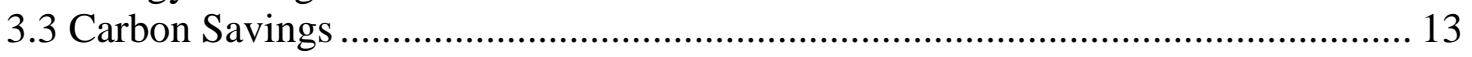

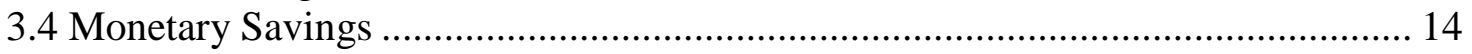

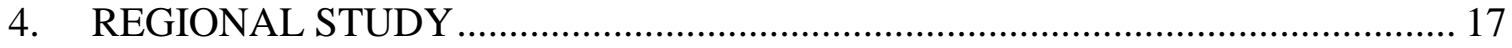

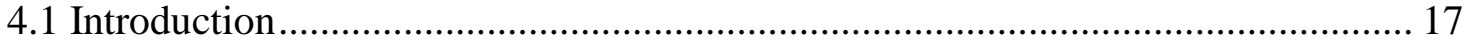

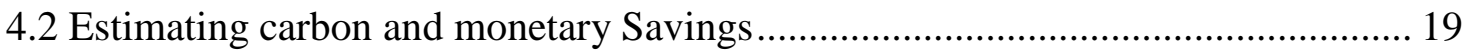

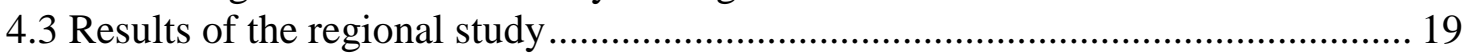

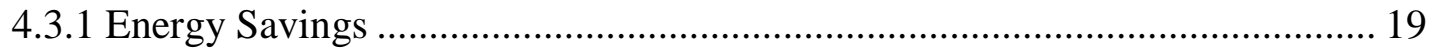

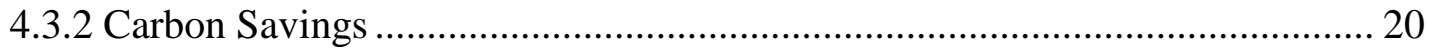

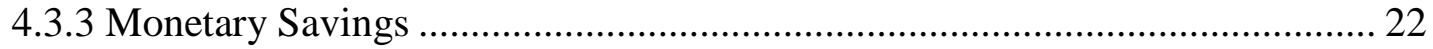

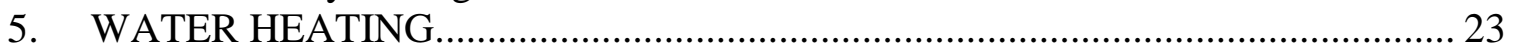

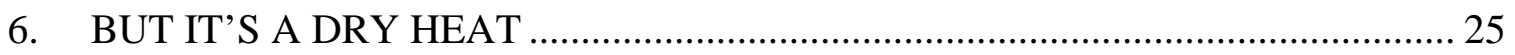

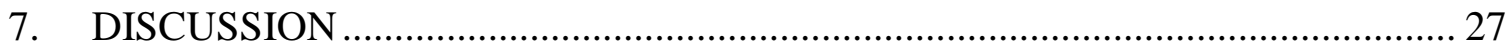

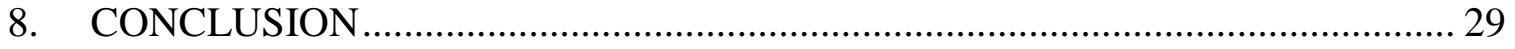

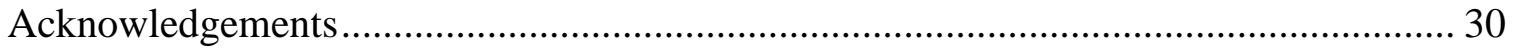

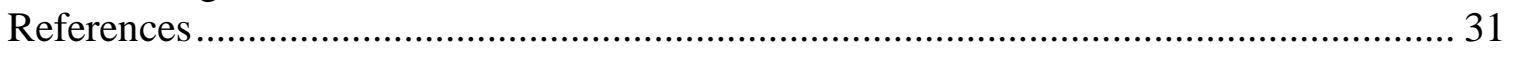

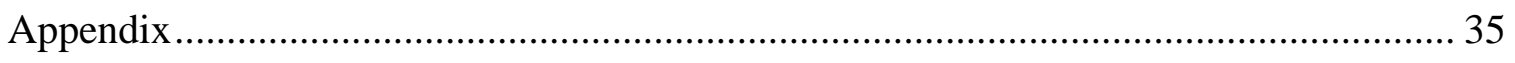


(THIS PAGE LEFT BLANK INTENTIONALLY) 


\section{LIST OF FIGURES}

Page

Figure 1. Monthly Per capita electricity supplied to residential customers (a), and commercial customers (b) in Florida, versus monthly temperatures for years 2002-2009 ... 6

Figure 2: Population-weighted cooling degree days (blue) and heating degree days orange) vs. temperature for January (left), April, (center), and July (right). Slopes of regression lines and percent variance in common $\left(\mathrm{R}^{2}\right)$ are also shown near each cluster of points. Data period is 1970-2009; spatial coverage is the contiguous USA................................ 8

Figure 3: Petroleum Administration for Defense Districts (PADDs) in the USA............ 11

Figure 4. United States Census Divisions by name and number and groupings of divisions into regions for this study. Our "Mountain" region is identical to Census Division 8 (Mountain Division). Census Division 9 (Pacific) includes Alaska and Hawaii; our "Pacific" region only inlcudes the contiguous states (California, Oregon, and Washington)

\section{LIST OF TABLES}

Page

Table 1. Links and References to Data Sources. ......................................................... 4

Table 2. Annual USA Primary Energy Savings (EJ) from .......................................... 13

Table 3. Annual USA Carbon Savings (Tg) from a.................................................. 14

Table 4. Annual USA Monetary Savings (millions of USA dollars) ............................. 14

Table 5. Annual Primary Energy Savings (EJ) from a $1^{\circ} \mathrm{F}$ Thermostat .......................... 20

Table 6. Annual Carbon Savings (Tg) from a $1^{\circ} \mathrm{F}$ Thermostat...................................... 21

Table 7. Annual Monetary Savings (millions of USA dollars) from a $1^{\circ} \mathrm{F}$..................... 22 
(THIS PAGE LEFT BLANK INTENTIONALLY) 


\section{LIST OF ACRONYMS}

ASHRAE American Society of Heating, Refrigeration, and Air-conditioning Engineers

BTU

CDD

DOE

British Thermal Unit

EIA

Cooling Degree Days

Department of Energy

EPA

Energy Information Administration

HDD Heating Degree Days

HERE Higher Education Research Experience Program

kW-h Kilowatt-hour

NCDC National Climatic Data Center

ORISE Oak Ridge Institute for Science Education

PADD Petroleum Administration for Defense District

SMSA Standard Metropolitan Statistical Area

ZEH Zero Energy House 
(THIS PAGE LEFT BLANK INTENTIONALLY) 


\section{INTRODUCTION}

It is generally agreed that there is no single solution to the problem of reducing energy use and the gaseous and particulate emissions arising therefrom. The problem must be approached from several angles. Notably, Pacala and Socolow (2004) have suggested 15 "wedges" each aimed at reducing carbon emissions; selection of which wedges to use, and the degree of implementation for each, is left to policymakers or individuals.

One of the more ambitious, but demonstrably achievable, ways to reduce energy use involves "zero energy" houses (ZEHs), which use little energy compared to most homes, or may be net producers of energy (Torcellini et al., 2006). Less ambitious measures provide correspondingly reduced benefits, in terms of energy and carbon savings, for individual households. These measures include use of compact fluorescent lights, windows that transmit light but not heat, and walls composed of structural insulated panels. Most of these measures save money over a period of years, if not almost immediately. The March 2009 issue of National Geographic Magazine had a feature article on energy savings starting in the home. It was shown that in many cases one can save energy, carbon emissions, and money all at the same time.

Among the easiest approaches to energy, and cost, savings for most people is the adjustment of thermostats to save energy. Here we estimate savings of energy, carbon, and money in the United States of America (USA) that would result from adjusting thermostats in residential and commercial buildings by about half a degree Celsius downward during the heating season and upward during the cooling season. To obtain as small a unit as possible, and therefore the least likely to be noticeable by most people, we selected an adjustment of one degree Fahrenheit, $\left(1^{\circ} \mathrm{F}\right)$ which is 0.56 degree Celsius $\left(0.56^{\circ} \mathrm{C}\right)$. This is the gradation used almost exclusively on thermostats in the USA and is the smallest unit of temperature that has been used historically.

Heating and/or cooling of interior building space for personal comfort is sometimes referred to as space conditioning, a term we will use for convenience throughout this work without consideration of humidity. Thermostat adjustment, as we use the term here, applies to thermostats that control the indoor temperature, and not to other thermostats such as those on water heaters.

We track emissions of carbon only, rather than of carbon dioxide, because carbon atoms change atomic partners as they move through the carbon cycle, from atmosphere to biosphere or ocean and, on longer time scales, through the rock cycle. To convert a mass of carbon to an equivalent mass of carbon dioxide (thereby including the mass of the 2 oxygen atoms in each molecule) simply multiply by 3.67 .

Our results are a set of factors for scaling a $1^{\circ} \mathrm{F}$ thermostat adjustment to the resulting savings of energy, carbon emissions, and money. Larger adjustments than $1^{\circ} \mathrm{F}$ will result in correspondingly larger savings increases as long as the indoor temperature does not closely approach the outdoor temperature, in which case savings would be reduced. Thermostat adjustments are easy to make, and the resulting comfort level can be determined by building occupants. We investigated only the residential and commercial sectors of the economy, where about half the total energy used goes for heating, ventilation and air conditioning according to the Residential and Commercial Energy Consumption Surveys conducted by the Energy Information Administration (EIA) of the United States Department of Energy (EIA, 2005, 2005a). The industrial sector uses large amounts of energy for manufacturing purposes such as machine drives, electrochemical processes, coking, and process heat, but less than $10 \%$ of the energy used by the industrial sector is used for heating and cooling (EIA, 2006). 
(THIS PAGE LEFT BLANK INTENTIONALLY) 


\section{METHODS}

\subsection{General Methodology}

\subsubsection{Introduction}

In this section, we present our generic methodology, including some introductory material about the relationship of energy use to air temperature. Methodological details are given in Section 2.2. We attempted to relate energy-use to temperature using a series of simple linear steps involving the concept of degree-days, discussed below. Because the relationships involved are not linear over the annual range of temperature, we used a series of linear relationships each corresponding to one calendar month. The use of individual calendar months also precluded aliasing of seasonal variables such as lighting and cooking that are not related to space conditioning but which use energy in an annual pattern that coincides with outdoor temperature. Calculations were done for the nation as a whole, and for each of four regions. Regional results were aggregated nationally for comparison with results for the nation as a whole. In general, the two approaches gave similar results although the regional calculations were more precise and summed to a national value about $12 \%$ higher than the results for the nation as a whole.

Energy use in buildings was measured by consumption of electricity, natural gas, and liquid fuel in the residential and commercial sectors. Energy derived from specific fuels is proportional to their respective heat contents, which are given in Appendix A of each issue of Monthly Energy Review, published by EIA. Once energy-use savings are estimated, corresponding savings in carbon and money can also be estimated. Oxidized carbon emitted per unit of heat realized from combustion of each of several commonly used fuels is given by the United States Environmental Protection Agency (EPA, 2012). Carbon emitted per unit of electricity generated, or delivered, can be approximated from the mix of fuels used by generating plants or by direct measurement of emissions (Rothschild et al., 2010), as discussed below. Monetary savings can be calculated from the price of energy to residential and commercial customers, which is readily available from sources identified in Table 1. This table serves as a convenient way of summarizing the large number of data sources we use. 
Table 1. Links and References to Data Sources.

\section{Degree-day data:}

National Climatic Data Center, Federal Building, 151 Patton Avenue, Asheville NC 28801-5001, Link: http://www1.ncdc.noaa.gov/pub/data/cirs/

Population Data: (U.S. Census Bureau) http://www.census.gov/

Heat Content of Various Fuels:

Appendix A of Monthly Energy Review. http://www.eia.doe.gov/emeu/mer/contents.html

Carbon Coefficients for various fuels:

EPA (United States Environmental Protection Agency), 2012. Inventory of United States

Greenhouse Gas Emissions and Sinks: 1990-2010, EPA 430-R-10-006, Annex 2, Tables A-32

and A33.

http://www.epa.gov/climatechange/Downloads/ghgemissions/US-GHG-Inventory-2012-Annex-

2-Emissions-from-Fossil-Fuel-Combustion.pdf

\section{Fuel Consumption and Prices}

Background Information: Consumption data for fuels and electricity by the various sectors of the economy are available from the Energy Information Administration (EIA), United States Department of Energy, 1000 Independence Ave., SW, Washington, DC 20585. Information about the hard copy issues and links to these monthly publications are provided below.

Monthly Energy Review DOE/EIA-0035 (year/mo) is the source of most of our national data; monthly values for all fuels, and for generation and sales of electricity, are given.

\section{National-Level Energy Data:}

Natural Gas: Monthly Energy Review, http://www.eia.doe.gov/emeu/mer/contents.html Residential and commercial consumption, in energy units, back through 1973 in Tables 2.2 and 2.3, respectively, prices back through 1984 in Table 9.11.

Electricity: Monthly Energy Review, http://www.eia.doe.gov/emeu/mer/contents.html Consumption back through 1973 in Table 7.6; prices back through 1995 in Table 9.9

\section{State/Regional-Level Data}

Household energy consumption: State Energy Profiles: http://www.eia.gov/beta/state/ Sources of Electricity for individual States: State Electricity Profiles: http://www.eia.gov/cneaf/electricity/st_profiles/e_profiles_sum.html

For any state, Table 5 gives generation by source; Table 10 gives electricity imports/exports.

Electricity Consumption: Electric Power Monthly DOE/EIA-0226 (year/mo). Provides stateby-state data for electricity sales and prices for each economic sector. Retail sales of electricity back through February, 2002 are available in archived spreadsheets:

http://www.eia.doe.gov/cneaf/electricity/epm/epm_ex_bkis.html 
Click on any month and go to Table 5.4.a; for electricity prices back through February 2002, follow the same path but go to Table 5.6.a. Issues lag reported values by 3 months.

Natural Gas: Natural Gas Monthly DOE/EIA-0130 (year/mo.): Provides state-by-state data for monthly natural gas deliveries for each economic sector. For residential deliveries, see: http://www.eia.gov/naturalgas/monthly/

\section{Petroleum}

No. 2 heating oil: Petroleum data by Petroleum Administration for Defense District (PADD) prime supplier sales volumes for No. 2 fuel oil back through 1983 are available via: http://tonto.eia.doe.gov/dnav/pet/pet_cons_prim_dcu_nus_m.htm

Prices for No. 2 Heating Oil (Petroleum Navigator Site) by state back through1983 via: http://www.eia.gov/dnav/pet/xls/PET_PRI DIST_DCU_NUS_M.xls

\subsubsection{Energy use and outdoor air temperature}

In Figure 1, we show the relationship between monthly mean outdoor air temperature for individual months and corresponding per capita electricity use, in kilowatt-hours (kW-h) per person, in the residential (a) and commercial (b) sectors of the economy in Florida for years 2002-09. Over 80\% of the households in Florida heat with electricity (i.e., electricity is generally used for both heating and cooling) according to the State Energy Profiles referenced in Table 1. The amount of electricity required for space conditioning does not change much between $60^{\circ}$ $\left(16^{\circ} \mathrm{C}\right)$ and $70^{\circ} \mathrm{F}\left(21^{\circ} \mathrm{C}\right)$, but increases as the outdoor temperature departs either way from that comfort zone. After fitting a quadratic curve to the plot of per capita residential electricity use vs. outdoor temperature (Figure 1a) the inflection point was calculated as $66.0^{\circ} \mathrm{F}\left(18.9^{\circ} \mathrm{C}\right)$. Use of data from an arid region might have led to a different inflection point.

In Figure $1 \mathrm{~b}$, which applies to the commercial sector, the inflection point is $61.6^{\circ} \mathrm{F}\left(16.4^{\circ} \mathrm{C}\right)$ and the slope of the curve does not depart from zero as much as it did for the residential sector at temperatures below that point. Commercial structures include restaurants, where appliances generate much internal heat that keeps indoor temperatures at or above the comfort level even when outdoor temperatures would require residential dwellings to heat for space comfort. Other commercial buildings include offices that may have even fewer appliances than most residential dwellings, although they may have office equipment to generate internal heat.

Commercial buildings frequently require less space conditioning than residential buildings during late-night or early-morning hours. The inflection point for commercial buildings likely varies from one type of building to the next, and from one region to another; as is well known to architects and engineers who design and construct such buildings. 

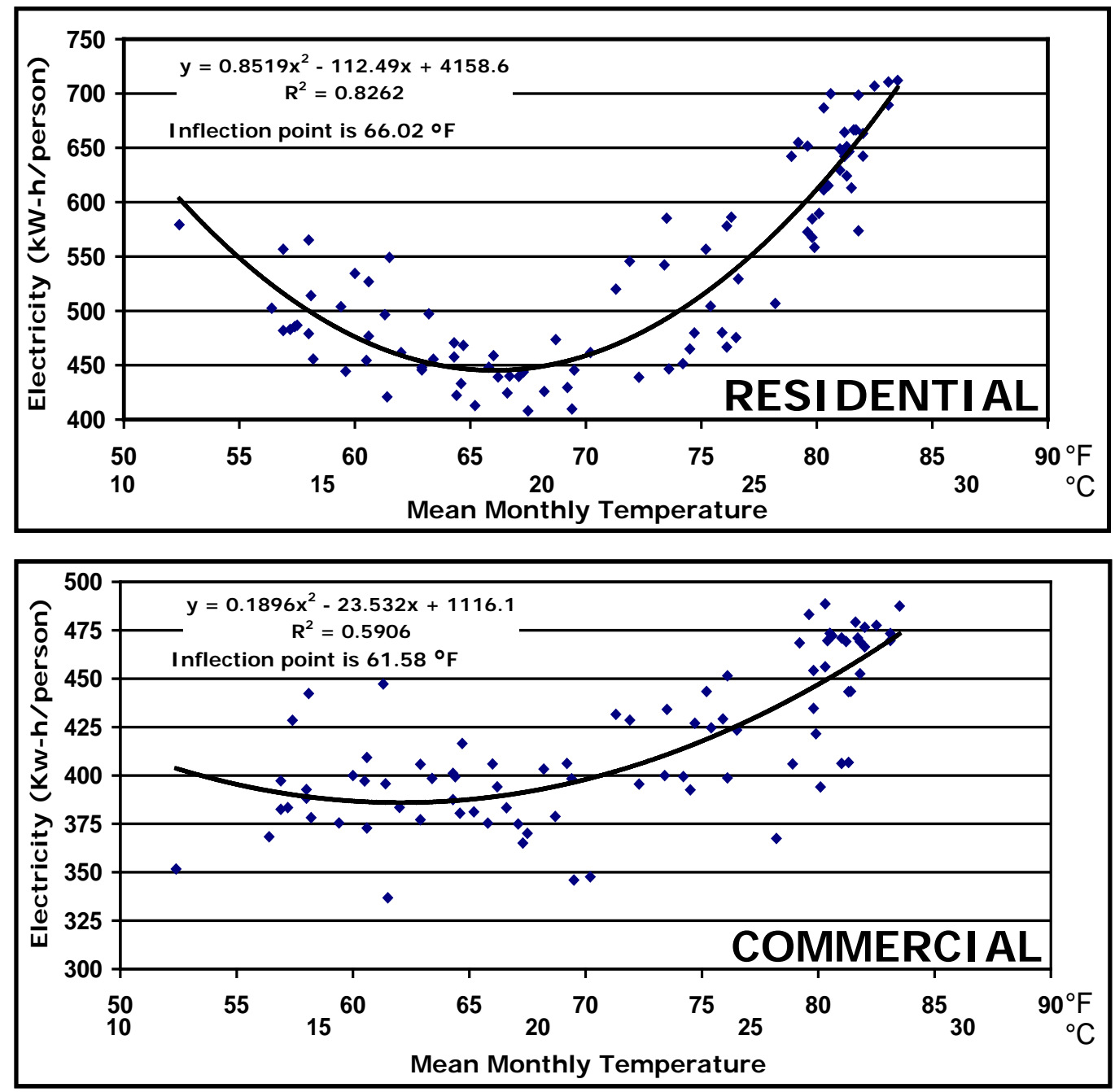

Figure 1. Monthly Per capita electricity supplied to residential customers (a), and commercial customers (b) in Florida, versus monthly temperatures for years 2002-2009.

\subsubsection{Heating and cooling degree-days}

In the absence of space-conditioning equipment, a one-degree change in outdoor temperature can be thought of as a one-degree change in indoor temperature. Once an indoor comfort level has been exceeded, adjusting that comfort level by one degree is considered equivalent to changing the outdoor temperature by one degree. When space-conditioning equipment is required to bring indoor temperatures to a comfortable level, the energy required is proportional to the difference between the outdoor temperature and the desired indoor temperature. These concepts are expressed numerically as heating degree days (HDD) or cooling degree days (CDD), which are calculated as the departure of the outdoor temperature from a comfortable value, which is typically taken to be around $18^{\circ} \mathrm{C}$. 
In the USA, the conventional value is $65^{\circ} \mathrm{F}$, which is approximately the inflection point in Figure 1a. Heating degree-days (HDD) are calculated by subtracting each daily average Fahrenheit temperature from 65 and cooling degree-days (CDD) are calculated by subtracting 65 from each average daily Fahrenheit temperature. Daily values are then aggregated into monthly values, so that both HDD and CDD can accrue during any given month, especially in a climatically moderate month when the average daily temperature is frequently above, and frequently below, $65^{\circ} \mathrm{F}\left(18^{\circ} \mathrm{C}\right)$ and some energy may be used for heating as well as for cooling. Use of a comfortbased variable increases the correlation with energy consumption for space comfort.

Heating and cooling degree-days are frequently used to estimate energy needed for space conditioning. Degree days are incorporated in the formulation of building codes (International Code Council, 2003), and used in practice (Lucas et al., 2007) by the American Society of Heating, Refrigeration and Air-Conditioning Engineers (ASHRAE) and other professional organizations. The United States Department of Energy and affiliated laboratories also use degree-days, and summaries of recent degree-day values are provided in each issue of Monthly Energy Review published by EIA. Researchers (e.g., Rosenthal et al., 1995, Hadley et al., 2006) frequently use degree-days for estimating energy requirements for space conditioning. While degree-days are the method of choice for estimating space conditioning needs from daily temperatures, the method has several shortcomings as conventionally practiced:

(1) Calculations are made from a base temperature of about $18^{\circ} \mathrm{C}\left(65^{\circ} \mathrm{F}\right)$. Use of that temperature is somewhat arbitrary; the most appropriate values might be different for heating than for cooling, and different values for either might be appropriate for different parts of the country. In restaurant kitchens, for example, cooling often starts well before outdoor temperatures reach $18^{\circ} \mathrm{C}$. This is because indoor temperatures are influenced by heat from ovens and stoves, incandescent light bulbs, and body heat from a high density of people. Rosenthal et al. (1995) used other base temperatures, including $10^{\circ} \mathrm{C}\left(50^{\circ} \mathrm{F}\right)$ for commercial buildings. The National Climatic Data Center is considering calculation of CDD from a variety of base temperatures (Vose, personal communication).

(2) Degree days are calculated from daily average temperatures. It might be better to calculate degree-hours if enough reliable climate data were available.

(3) Because energy use for space conditioning is limited during periods of moderate temperature, the relationship between degree-days and temperatures is not linear over the course of a year. Thus, for example, in the southern USA, energy requirements for space cooling would not be much different in a warm April than in a cold one.

In spite of these shortcomings, degree-days are believed to be a reasonable approach to approximating energy savings resulting from changes in thermostat settings. We obtained temperature and degree-day data from the National Climatic Data Center (NCDC) as indicated in Table 1. These data are available at the national, regional and state level and based on $65^{\circ} \mathrm{F}$. In an area as large as the USA, temperature anomalies are frequently of one sign in much of the country and of the opposite sign in the remainder. Degree-days are weighted by population, to provide a better match to national energy-use anomalies than would (area-weighted) temperature. Analyzing smaller areas further improves the correlation between degree-days and energy use, although our national study led to about the same results as those obtained when we considered four regions separately and combined the results to obtain a national total.

This degree of agreement in results was largely due to the population weighting of degree-day data. Using many years of data for any particular calendar month, a regression-based straight-line 
equation can be used to estimate monthly degree-days from monthly mean temperature. In Figure 2 we show the relationship of national (area weighted) monthly average temperature to national (population-weighted) average degree-days for January, April and July. There are many more HDD than CDD indicating that space heating dominates space cooling in the USA.

The slopes of the lines in Figure 2 are in units of degree (F) days per degree (F), or days. They can vary from almost zero, when the number of days in a month requiring a particular mode of space conditioning is essentially zero, to small values during climatically moderate months, and further to the number of days in a month for months when heating (or cooling) is required continuously everywhere within the area of study. In January, the HDD slope is -27 indicating that heating is not needed 24 hours of every day in some parts of the nation. In July the slope of the CDD line indicates that air conditioners would be needed only about 56 percent (17.4/31) of the time (including day and night), on average, over the USA.

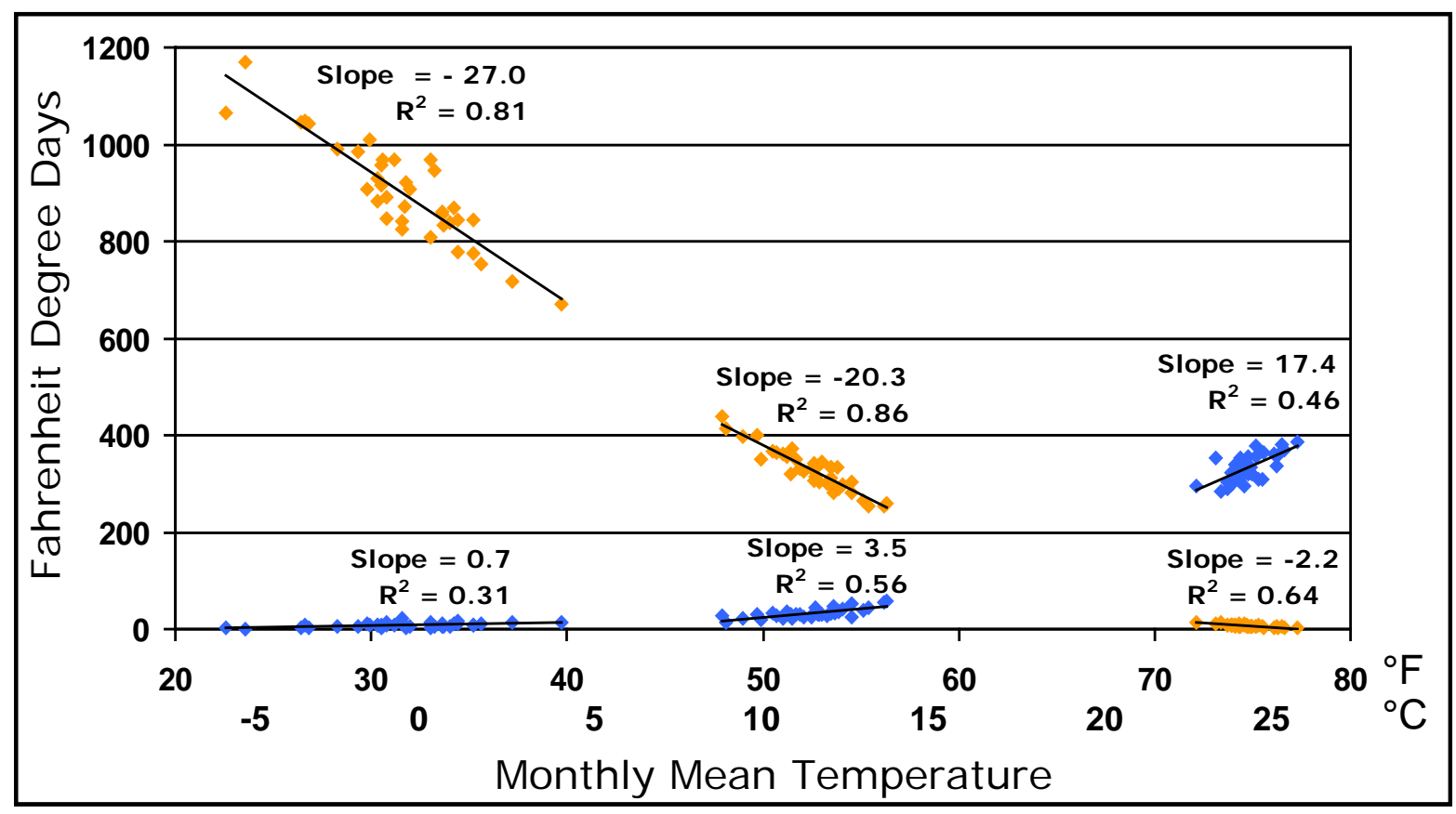

Figure 2: Population-weighted cooling degree days (blue) and heating degree days orange) vs. temperature for January (left), April, (center), and July (right). Slopes of regression lines and percent variance in common $\left(R^{2}\right)$ are also shown near each cluster of points. Data period is 1970-2009; spatial coverage is the contiguous USA.

When space conditioning is required, one can think of the energy required for a one-degree adjustment of indoor temperature as equal to a one-degree increase in outdoor temperature. Where space conditioning is required 24-hours a day, the heater or air conditioner is on for a certain percentage of the time, which depends on the amount of space conditioning, required (the difference between outdoor temperatures and the comfort level). If this constant need for space conditioning persists for an entire month, day and night, the slope of the line in Figure 2 will approach the number of days in the month. If no space conditioning is required in the evening hours, the slope might be around half of the number of days in a month, and if space conditioning is required only a few days, the slope would be even less. 
The range of CDD in July is around 100 but in April, a moderate month, that range is only about 40. In our regional study we derived separate sets of regression lines for four regions of the USA, and this led to slopes approaching the number of days in a month for HDD during the coldest summer months in the north, and for CDD during the hottest months in the south, as the temperature ranges were extended beyond those in Figure 2.

Analysis of each calendar month separately minimized effects of lighting, cooking, and other seasonally variable energy uses not related to space comfort. Water heating remained the major use of energy that is thermally influenced but not related to space conditioning. More energy would be used in a cold December than in a warm one or in a warm July than in a cool one. These influences combine to produce an estimated high bias of about $0.2 \%-0.3 \%$ in our estimated savings, as elaborated in Section 5. The material that follows did not account for this bias.

Approximations used always bias the results. In many cases this led to a high bias (i.e., our estimates are higher than true values) and in other cases a low bias may have resulted. We have attempted to provide some idea of the direction and magnitude of these biases, although they are sometimes difficult or impossible to quantify and/or to document. Where a bias is given as a percentage, it is in terms of our calculated result (i.e., $1 \%$ means $1 \%$ of our calculated result).

\subsubsection{Estimating energy savings}

Energy-use data were converted to per capita figures to eliminate influences of population trends. This statistic seems more meaningful in the residential sector than in the commercial sector, but in either case, it measures average energy consumption per person. Population estimates were obtained from the United States Census Bureau (2012). Table 1 provides the reference and link to this material. These estimates apply to July 1 each year. Monthly values were interpolated between Julys. Results of the 2010 census altered our findings by less than $1 \%$ of the values we give here.

Energy and degree-day data were also first-differenced to minimize influences of any other trends that might be due to such things as fuel switching, increases in size of the average home, the number of air-conditioners per capita, or climate change. Eliminating influences of climate trends could have biased our results downward, but trend was only about $5 \%$ or less of the standard deviation, or of the average absolute departure from the mean. It is not clear whether we failed to include real phenomena or avoided inclusion of false correlations (e.g., with coincident trends in use of electronic appliances) by removing effects of trends in climate.

Per-capita energy consumption was then estimated from degree-day data for each calendar month using simple linear regression. These energy-consumption estimates represent the thermally driven component of total energy consumption. The slopes of the regression line are then in units of energy per person-month-degree-day.

When multiplied by the slope of the regression line-fitting degree-days to average temperature for the corresponding month, (in units of degree-days per degree) we obtained the thermally driven component of energy use per person-month-degree:

$\frac{\text { energy }}{\text { person-month-degree-days }} \cdot \frac{\text { degree days }}{\text { degree }}=\frac{\text { energy }}{\text { person-month-degree }}$

Note that the ratio of degree-days per degree is a unit of time, and provides an indicator of the time that space-conditioning equipment is needed for space comfort. It also relates outdoor 
temperature (degrees) to a measure of energy needed for a given level of space conditioning (degree-days).

Regression equations to estimate energy use from degree-day data were rejected if they did not pass a two-tailed t test at the 95\% confidence level. This worked for about all the cases one would expect, although occasionally one month's savings were not included due to poorness of fit. This may have resulted in a slight underestimate of savings.

The next step was to use equation 2 to calculate carbon and monetary savings for each calendar month resulting from a $1^{\circ} \mathrm{F}$ thermostat adjustment to save energy.

$\frac{\text { energy }}{\text { person-month-degree }} \quad \cdot \quad \frac{\text { carbon or money }}{\text { energy }}=\frac{\text { carbon or money }}{\text { person-month-degree }}$

Multiplying the right hand side of Equation 1 or 2 by the population gives the total national monthly savings for the area under consideration. Average household savings were estimated originally using the (2009) Census Bureau estimate of 2.57 persons per household. This ratio remained virtually unchanged (2.58 persons per household) in the 2010 Census.

\subsection{Methodological details}

\subsubsection{Sources of national energy data}

Detailed references and links to our data sources are given in Table 1. National-level data on natural gas and electricity consumption for each sector of the economy are found in Monthly Energy Review, published monthly by EIA. Electricity data are always given in terms of kilowatthours (kW-h). Energy from natural gas at the national level is given in British Thermal Units (BTUs) where 3413 BTUs $=1 \mathrm{~kW}-\mathrm{h}$

Estimation of savings from petroleum products was problematic. Temporal precision is obscured by the time lag between fuel delivery and consumption. State data for individual months are frequently not available or "withheld to avoid disclosure of individual company data" This problem tends to occur where relatively little heating fuel is provided by a small number of suppliers. Such regions are primarily outside of the northeastern USA; errors in attempting to estimate heating oil consumption in these regions could be of the same magnitude as the estimates themselves.

Some reasonably consistent time series are given for prime-supplier sales volumes in some of the Petroleum Administration for Defense Districts (PADDs); there are five PADDs in the USA, as shown in Figure 3. We confined our studies to sales of No. 2 (heating) oil in PADDs 1a, 1b, and 2 and did not attempt to proceed further. These PADDs collectively account for over $90 \%$ of No. 2 fuel oil in the USA. About $6.5 \%$ of homes in the USA heat with liquid petroleum gas (See link to State Energy Profiles given in Table 1).

Some No. 2 fuel oil is not used for space heating, but that which is provides a high correlation between its overall use and variations in degree days (average correlation coefficient for December, January, and February $=0.73$ ). Not considering the No. 2 fuel used outside of PADDs $1 \mathrm{a}, 1 \mathrm{~b}$, and 2, or of liquid petroleum fuels anywhere led to a nontrivial low bias of $5-10 \%$ of our calculated national energy savings for heating, and of a few percent in our overall savings 
estimates. Most home-heating oil in the USA is consumed in the northeastern part; variations in this consumption are not much influenced by temperature anomalies elsewhere.

Therefore, we used population-weighted heating degree-days for U.S. Census Divisions 1-4, which coincides closely, but not exactly, with the area covered by PADDs 1a, $1 \mathrm{~b}$ and 2.

(Oklahoma, Tennessee, Kentucky, Maryland, Delaware and the District of Columbia are included in these PADDs, but not in Census Divisions 1-4).

\subsubsection{Estimating carbon and monetary savings}

The amount of carbon emitted per unit of energy consumed varies from one fuel to the next. Carbon emissions factors (carbon emitted per 1000 BTU or per $1.055 \mathrm{MJ}$ ) are published by the United States Environmental Protection Agency (EPA) in Appendix 2 of EPA (2012). Emissions factors for natural gas and No. 2 heating oil are 13.71 and 19.12 grams of carbon per megajoule, respectively. The emissions factor for electricity (g/ kW-h) for the United States as a whole was calculated as the carbon emissions from total electricity generation divided by the total number of kilowatt-hours generated. Because the United States imports and exports only negligible amounts of electricity compared to the national totals (EIA, 2012), emissions from generation can be taken to equal emissions from consumption.

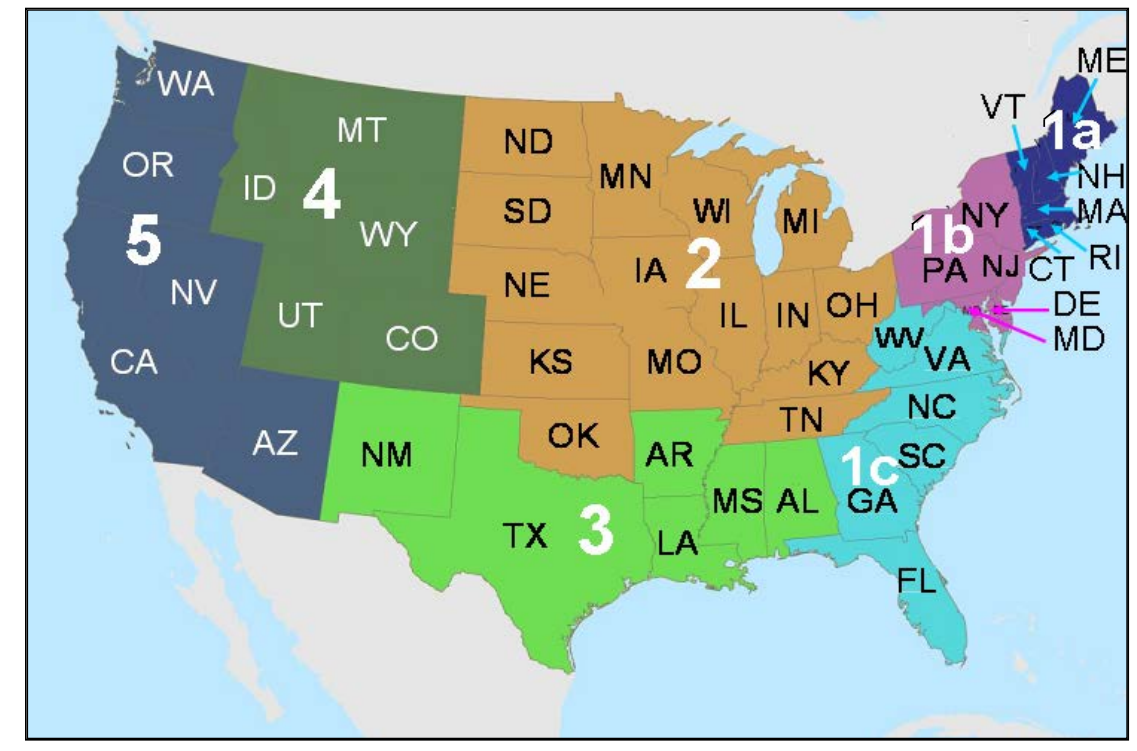

Figure 3: Petroleum Administration for Defense Districts (PADDs) in the USA.

This is not true on a state-by-state basis, where imports or exports frequently constitute a large percentage of a state's electricity use (EIA, 2012a) thereby complicating calculations of carbon emitted per kW-h consumed for individual states - a topic discussed below under regional studies.

Only around $90 \%$ of electricity generated is delivered to customers; the remainder is used by generating plants or is lost as heat and electromagnetic energy in the lines and transformers used in delivery (EIA, 2012). USA fossil carbon emissions per kW-h leaving a generating facility in year 2005 were on average about 1.33 lbs. of carbon dioxide per kW-h, or 164.4 grams of fossil carbon per kW-h (Rothschild and Diem, 2009). Energy used by power plants is accounted for in this figure, but not energy lost in lines and transformers. Multiplication by 1.062 to allow for 
these transmission and delivery losses (Rothschild and Diem, 2009) gives $0.175 \mathrm{~kg}-\mathrm{C} / \mathrm{kWh}$, which is the value we used for our national study.

This value has likely decreased somewhat in recent years, which would lead to a high bias in our estimated carbon savings. However, much of our calculated savings occur during very cold or very warm periods, which tend to have greater percentages of generated energy that are non-base load, or energy generated during periods of peak demand. In general, this extra energy is generated from fossil fuels and tends to have somewhat higher emissions per $\mathrm{kW}$-h generated than base load energy, which is the more-or-less constant supply of electricity used for appliances, lighting, etc. The net effect of these conflicting biases (use of dated data and of baseload emissions values) is unclear.

Volumes of heating oil from prime suppliers were converted to energy units using the heat content value for distillate oil in Appendix A of each issue of Monthly Energy Review (=38.7 megajoules per liter). As sales of heating oil are not broken down by sector, we arbitrarily assigned them all to the residential sector.

\subsubsection{Cost of energy}

Energy prices to customers in the residential and commercial sectors were calculated for each month using average values from 2005 to 2009. The price of natural gas for each sector of the economy is given in Table 9.11 of Monthly Energy Review in units of dollars per 1000 cubic feet which we then converted to the price of energy by the same general procedure as for heating oil above, using annual conversion factors (typically 1028 BTU/cubic foot, or 38.3 megajoules per cubic meter) from Appendix A of Monthly Energy Review. Electricity prices are given for each economic sector in Monthly Energy Review.

Number 2 distillate oil prices for the residential sector were obtained from the Petroleum Navigator site (see Table 1). Data are given in units of cents per gallon, excluding taxes, and therefore include a low bias. We weighted these data by PADD and converted to \$/million BTU before proceeding from there to obtain $\$ / \mathrm{kW}$-h. It should be noted that price data are subject to rapid change. We used residential prices only, introducing a high bias to counteract the low bias due to exclusion of taxes. Because heating oil accounts for a small percentage of national energy use for space heating, the result is a small net bias of unknown direction in our estimates of cost savings.

\subsubsection{Cost of emitting a kg of carbon}

Dividing the cost of a unit of energy by the amount of carbon emitted per unit of energy gives the cost of a unit of carbon (e.g., $\$ / \mathrm{kg}-\mathrm{C}$ ). This figure is useful for comparison with suggested carbon taxes (which are usually given in money per mass of carbon dioxide). 


\section{RESULTS OF THE NATIONAL STUDY}

\subsection{Introduction}

The United States is large enough that some areas may experience below normal temperatures while other areas within the country may have above normal temperatures during the same season. Averaging across the nation is therefore subject to cancellation effects and may not be as accurate as if the calculations were done for smaller regions and the results aggregated nationally. Nonetheless, our first attempt was at the national level in order to provide a reasonable lower bound on the general magnitude of the expected savings.

\subsection{Energy Savings}

Table 2 shows the national annual energy savings, in Exajoules (EJ), for a $1^{\circ} \mathrm{F}$ thermostat adjustment in residential and commercial buildings. We consider primary energy that includes delivered energy plus energy losses in lines and transformers and energy used to run power plants. It also includes energy that is lost as a consequence of the second law of thermodynamics when heat energy realized from fuel combustion is transformed into electrical energy or passes through a heat exchanger; for electricity, these losses take place at the generating facility; for fuel oil or natural gas they take place in the heat exchanger of the furnace that heats a building.

Table 2. Annual USA Primary Energy Savings (EJ) from a $1^{\circ} \mathrm{F}$ Thermostat Adjustment to Save Energy

\begin{tabular}{|l|r|r|r|r|r|}
\hline & \multicolumn{2}{|l|}{ Residential } & \multicolumn{2}{l|}{ Commercial } & \multicolumn{2}{l|}{ Totals } \\
\cline { 2 - 6 } & \multicolumn{1}{|l}{ Heating } & \multicolumn{1}{l|}{ Cooling } & \multicolumn{1}{l|}{ Heating } & Cooling & \\
\hline Electricity & 0.048 & 0.120 & 0.008 & 0.047 & 0.223 \\
\hline Natural Gas & 0.132 & & 0.058 & & 0.190 \\
\hline Fuel Oil & 0.018 & & & & 0.018 \\
\hline Totals & 0.198 & 0.120 & 0.066 & 0.047 & $\mathbf{0 . 4 3 1}$ \\
\hline
\end{tabular}

Energy saved from heating exceeds that for cooling even though everything was scaled to a $1^{\circ} \mathrm{F}$ thermostat adjustment. This is primarily because more heating than cooling is needed in most parts of the US. Total savings are largest for electricity, which would be expected due to the large energy losses involved in producing and transporting electricity. Only about one-third of the heat realized from fuel combustion is converted to electricity in accordance with the second law of thermodynamics.

\subsection{Carbon Savings}

Table 3 shows the annual savings in carbon emissions resulting from a $1^{\circ} \mathrm{F}$ thermostat adjustment to save energy in the residential and commercial sectors of the economy. As with energy, carbonemissions savings from heating outweigh those for cooling in both sectors, and savings are greatest for electricity.

National carbon savings (6.4 Tg-C) were compared with national emission totals for the USA, taken to be $1500 \mathrm{Tg}$ annually (including gas flaring and cement manufacture but excluding emissions from U.S. territories and from international bunker fuels). This value for national emissions is consistent with values for recent years given by Boden et al. (2012, 2012a) 
Table 3. Annual USA Carbon Savings (Tg) from a $1^{\circ} \mathrm{F}$ Thermostat Adjustment to Save Energy

\begin{tabular}{|c|c|c|c|c|c|}
\hline & \multicolumn{2}{|l|}{ Residential } & \multicolumn{2}{|l|}{ Commercial } & \multirow[t]{2}{*}{ Totals } \\
\hline & Heating & Cooling & Heating & Cooling & \\
\hline Electricity & 0.736 & 1.858 & 0.116 & 0.715 & 3.425 \\
\hline Natural Gas & 1.811 & & 0.793 & & 2.604 \\
\hline Fuel Oil & 0.352 & & & & 0.352 \\
\hline Totals & 2.899 & 1.858 & 0.909 & 0.715 & 6.381 \\
\hline
\end{tabular}

Approximately 0.43 percent of USA carbon emissions could be erased by a $1^{\circ} \mathrm{F}$ adjustment of all residential and commercial thermostats to save energy used for space comfort. The Census Bureau estimated the USA 2009 population as about 307 million persons, and $0.43 \%$ of that number is over 1.3 million persons whose carbon footprints could be erased by a $1^{\circ} \mathrm{F}$ thermostat adjustment.

For another comparison, this carbon savings would be equivalent to erasing the carbon footprint of over 5 million automobiles (average distance and fuel economy from Davis et al. (2012), and assuming $2.43 \mathrm{~kg}-\mathrm{C}$ (8.92 kg-CO ${ }_{2}$ ) are emitted per gallon used, as per EPA (2012a).

\subsection{Monetary Savings}

Table 4 shows the annual monetary savings corresponding to the carbon and energy savings above. Annual savings for the nation as a whole were estimated as almost 4.6 billion dollars.

Over 3.5 billion dollars of this was in the residential sector, from which it seems meaningful to calculate the annual per capita savings as about $\$ 11$ per person. Census bureau figures give the average number of people per household as 2.58. Our estimated savings from national-level calculations are about $\$ 29$ per household per year per $1^{\circ} \mathrm{F}$ thermostat adjustment to save energy.

Table 4. Annual USA Monetary Savings (millions of USA dollars) From a $1^{\circ} \mathrm{F}$ Thermostat Adjustment to Save Energy

\begin{tabular}{|c|c|c|c|c|c|}
\hline & \multicolumn{2}{|l|}{ Residential } & \multicolumn{2}{|l|}{ Commercial } & \multirow[t]{2}{*}{ Totals } \\
\hline & Heating & Cooling & Heating & Cooling & \\
\hline Electricity & 427 & 1,183 & 62 & 410 & 2,082 \\
\hline Natural Gas & 1,575 & & 604 & & 2,179 \\
\hline Fuel Oil & 311 & & & & 311 \\
\hline Totals & 2,313 & 1,183 & 666 & 410 & 4,572 \\
\hline
\end{tabular}

Energy savings per degree (F) of thermostat setting in winter only have been calculated for year 1997 by the U.S. Department of Energy, (EIA, 2009) based on several assumptions, some of which could not be avoided. However, they essentially assumed that the slopes of the regression lines in Figure 2 did not vary with temperature, which leads to nontrivial overestimates of the energy consumed. Additionally, it is not clear how EIA accounted for the thermally driven effects of water heating, or increased lighting and cooking during the coldest months. Dividing our costs 
for electricity and natural gas in Table 4 by the number of households using each respective fuel, according to State Energy Profiles cited in Table 1, and adjusting for price differences between 1997 and our 2005-2009 averages gives figures for comparison. We get \$14/year savings for natural gas, EIA got \$22; we got \$9 for electricity, EIA got \$16. While differences in energy efficiency since 1997 could explain some of this, it could also be at least partly due to some combination of a high bias in the EIA estimates and a low bias in ours.

Unlike carbon savings (Table 3), dollar savings for electricity (Table 4) were about the same as those for natural gas. This is because our prices were based on the amount of energy delivered to a residential or commercial building; energy lost to generate and deliver electricity occurs before delivery, while energy lost from natural gas combustion in a furnace of a residence or commercial building occurs after delivery. Another factor is appreciable price increases for natural gas and oil in the years we used (2005-2009) to derive our price figures.

The dollar cost of emitting a kg of carbon for energy used in homes or commercial buildings can be calculated by dividing the total dollar savings by the total carbon savings. For the period 20052009 , this was around $\$ 0.60 / \mathrm{kg}-\mathrm{C}$ for electricity, $\$ 0.84 / \mathrm{kg}-\mathrm{C}$ for natural gas, and $\$ 0.88$ for no. 2 heating oil. Suggested carbon taxes may be compared to these figures; if a suggested tax is given in terms of carbon dioxide rather than carbon, multiply the given figures by 3.67 before comparing with those above. 
(THIS PAGE LEFT BLANK INTENTIONALLY) 


\section{REGIONAL STUDY}

\subsection{Introduction}

Regional studies would be expected to provide more accurate estimates of carbon emitted per degree of thermostat adjustment because the energy use anomalies are in closer spatial proximity to the degree-day anomalies used in the calculation. Regional studies also reflect more closely the details involved, and should, when aggregated to the national level, indicate about the same or somewhat greater savings than calculated from national data only.

However, data often become limiting to such studies, as spatially refined data are more difficult to obtain than are nationally aggregated data.

We divided the country into 4 regions (Figure 4) consisting of the northeast (U.S. Census Divisions 14), the Southeast, (Census Divisions 5-7), Mountain (Census Division 8) and Pacific (Census Division 9). The first 2 regions dominate the country in population and therefore in energy use, carbon emissions, and total energy costs. The other regions are of interest for their own sake. The Mountain region has large areas in the northern and southern United States, so no clear seasonal dominance is evident. The Pacific states, where most people live in climatically moderate areas, have about half the hydropower sources in the USA, and use appreciably less fossil fuels per capita than the rest of the country.

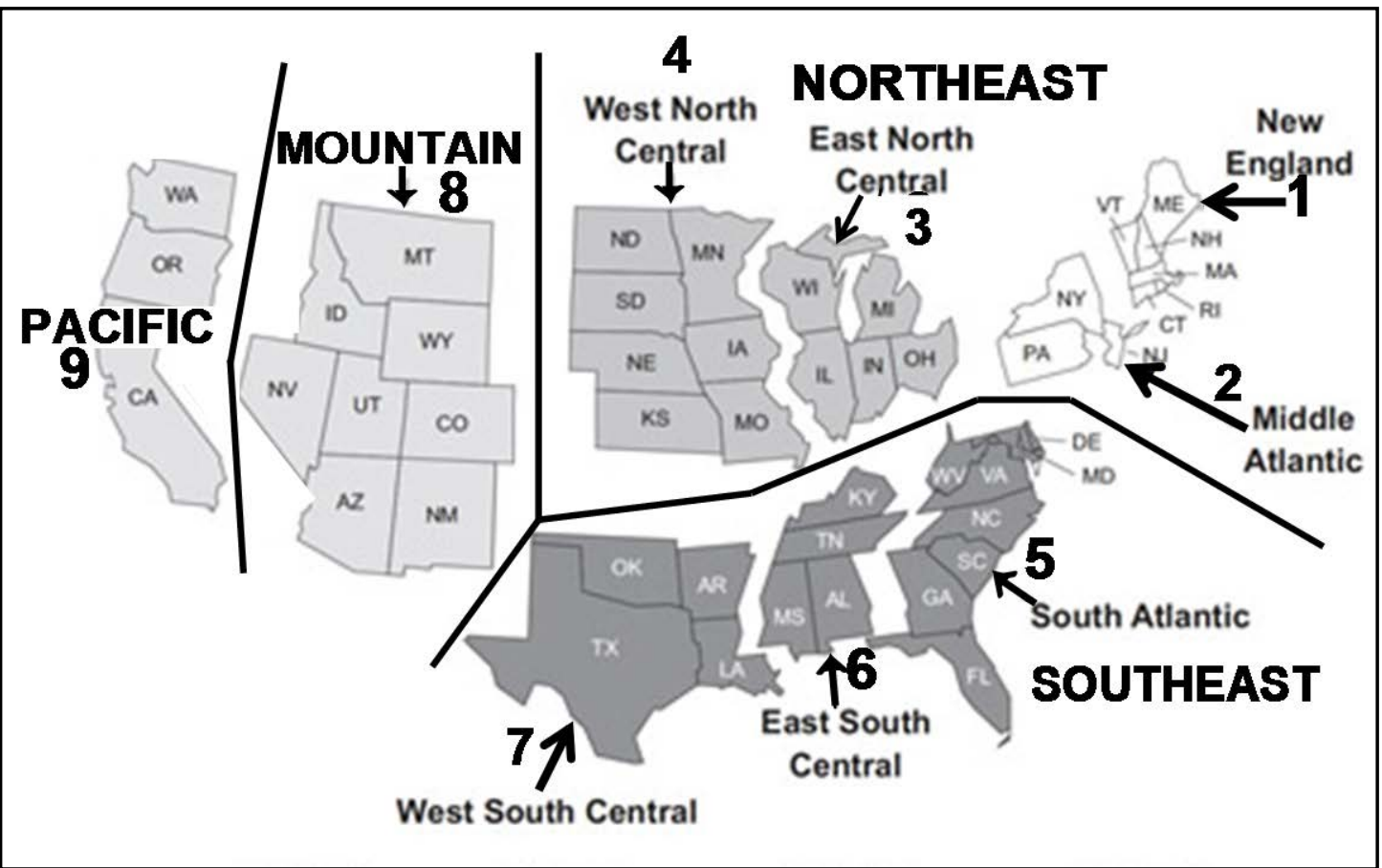

Figure 4. United States Census Divisions by name and number and groupings of divisions into regions for this study. Our "Mountain" region is identical to Census Division 8 (Mountain Division). Census Division 9 (Pacific) includes Alaska and Hawaii; our "Pacific" region only inlcudes the contiguous states (California, Oregon, and Washington). 
Digitized degree-day data for states and census divisions are available from the National Climatic Data Center (NCDC). We weighted the census-division data by population to obtain data for our 4 regions. The population weighting assures that degree-days incorporate the number of people using heating or air conditioning equipment.

While our methodology for the regional study was generically similar to the national-level study, above, it was much more limited in terms of energy-use data. Monthly electricity data for each state and economic sector are published in Electric Power Monthly (See Table 1 for references and links). These data only begin in February 2002. Amounts of fuels used to generate electricity are recorded over a longer period, but electrical energy is used far from where it is generated, and this study involves consumption rather than generation.

With only 8 data points for electricity consumption for most months (7 for January), generally accepted statistical significance levels are seldom attained regardless of the goodness of fit. We therefore lowered the acceptability criterion of a linear fit to 4-1 odds in the expected direction (1tailed t test giving $80 \%$ confidence); which eliminated some cases, mostly involving HDD in the commercial sector, especially in the Southeast region of the country. In some other cases, the CDD were not well correlated with warm season temperatures in the commercial sector. In general, relationships excluded by this procedure were similar to those excluded by the more rigorous procedure for the national study used above. Because of the small number of data points and the lack of obvious trends, we did not first difference the data and thereby lower the number of data points even further.

Twenty years (1989-2008) of almost complete natural gas sales and price data were available on a state-by-state basis in Natural Gas Monthly, so we could afford to return to the statistical-fit criterion used in our national study. We also used first differences of the data because a longer data period increases the likelihood of long-term trends unrelated to temperature and/or to degree-day totals. The data are given in cubic feet of natural gas, and we used the (nationally aggregated) heat-content values in Table A-4 of each issue of Monthly Energy Review to convert these data to BTUs and then to kW-h or MJ (1 kW-h = $3413 \mathrm{BTU}=3.6 \mathrm{MJ})$.

In our national-level study, we only considered heating oil from PADDs 1a, 1b, and 2. The collective area covered by these PADDs corresponds closely with United States Census Divisions 1-4, which we designated as the "Northeast" in our regional studies. As noted above, the PADDs include 5 states (Oklahoma, Tennessee, Kentucky, Maryland and Delaware) and the District of Columbia that are not included in the 4 census divisions we grouped as the Northeast. Degree-day anomalies in those states are not likely to be much different from those in the 4-division region. Essentially we assumed all sales of Number 2 heating oil in the 3-PADD area occurred in the census divisions 1-4, which is not far from reality, and which is as close as deemed necessary for our level of approximation. The resulting high bias in overall heating savings for the northeastern region would be more than cancelled at the national level by neglecting use of heating oil outside of PADDs 1a, 1b, and 2. Neglect of this heating oil, and of liquid petroleum gas, would lead to a nontrivial low bias in heating savings, 5-10\% of our estimated value for the nation as a whole, and of a few percent in our overall savings estimates from heating and cooling. 


\subsection{Estimating carbon and monetary Savings}

To calculate the amount of carbon emissions per kilowatt-hour consumed, one needs to know how the electricity was generated. This varies considerably from time to time and place to place within the country. Aggregated numbers for each state are available in Rothschild and Diem (2009).

Losses of electrical energy occur in transmission from the generating plants and distribution to consumers. Therefore, some multiplier is needed to account for the carbon emitted in generating the electricity lost in transmission. EIA uses 7\% (AER) while Rothschild et al. (2010) suggest the national value is closer to $6 \%$. We approximated by applying the values given by Rothschild et al. (2010) for the eastern grid to our Northeast and Southeast regions, and their values for the western grid to our Mountain and Pacific regions. The transmission issue raises 2 other difficult but related questions: (1) How much electricity consumed in a state or region was actually imported from other places; (2) How much electricity generated in a region was exported to other places. As noted above, the net imports for the USA as a whole are less than $1 \%$ of the amount generated (EIA, 2012). However, this is not true or even acceptably close to true, for some areas within the country.

For information on the net transfer of electricity, we consulted the State Electricity Profiles (See Table 1 for reference information) and summed imports and exports over the states within each of our selected regions. Exporting regions (Northeast and Mountain) were assumed self-sufficient and importing regions (Southeast and Pacific) were assumed to use their own generated electricity and to import the rest. Imports for the Southeast were factored in as though they all came from the Northeast, and imports for the Pacific section were factored in as though they were all from the Mountain section, although California imports a small amount from Mexico. State energy prices were obtained from Electric Power Monthly (Table 5.6) and Natural Gas Monthly and (Tables 14-23) the populationweighted average (2005-2009) prices for each month were then calculated for each of our regions. Results are shown and discussed below. Number 2 distillate oil has been discussed in Section 2.2.3.

\subsection{Results of the regional study}

\subsubsection{Energy Savings}

Energy savings by region and for the nation as a whole are summarized in Table 5. National savings from heating are greater than from cooling, mostly due to the length of the heating season in the Northeast. Savings from cooling are greatest in the southeast, as would be expected. Total savings for the nation are greatest in the northeast, where the greatest numbers of people live.

Savings for the Mountain section are somewhat higher for heating than for cooling, as the heating season is longer than the cooling season over much of the region. The Pacific states enjoy a moderate climate that requires relatively little air conditioning.

Total savings is $0.482 \mathrm{EJ}$; USA primary energy supply (not including exports) for 2009 (the latest year for which data were available as this was written) was $99.68 \mathrm{EJ}$, so the energy savings would be $0.48 \%$ of the nation's supply. 
Table 5. Annual Primary Energy Savings (EJ) from a $1^{\circ} \mathrm{F}$ Thermostat Adjustment to Save Energy for 4 Regions in the USA

\begin{tabular}{|c|c|c|c|c|c|}
\hline & \multicolumn{2}{|l|}{ Residential } & \multicolumn{2}{|l|}{ Commercial } & \multirow[t]{2}{*}{ Totals } \\
\hline & Heating & Cooling & Heating & Cooling & \\
\hline \multicolumn{6}{|l|}{ Northeast } \\
\hline Electricity & 0.015 & 0.063 & 0.003 & 0.020 & 0.101 \\
\hline Natural Gas & 0.070 & & 0.029 & & 0.099 \\
\hline Fuel Oil & 0.018 & & & & 0.018 \\
\hline Regional Totals & 0.103 & 0.063 & 0.032 & 0.020 & 0.218 \\
\hline \multicolumn{6}{|l|}{ Southeast } \\
\hline Electricity & 0.023 & 0.085 & * & 0.031 & 0.139 \\
\hline Natural Gas & 0.033 & & 0.014 & & 0.047 \\
\hline Regional Totals & 0.056 & 0.085 & 0.014 & 0.031 & 0.186 \\
\hline \multicolumn{6}{|l|}{ Mountain } \\
\hline Electricity & 0.003 & 0.009 & 0.001 & 0.004 & 0.017 \\
\hline Natural Gas & 0.008 & & 0.005 & & 0.013 \\
\hline Regional Totals & 0.011 & 0.009 & 0.006 & 0.004 & 0.030 \\
\hline \multicolumn{6}{|l|}{ Pacific } \\
\hline \multicolumn{6}{|l|}{ Electricity } \\
\hline Natural Gas & 0.008 & 0.005 & 0.005 & 0.001 & 0.019 \\
\hline \multirow[t]{2}{*}{ Regional Totals } & 0.021 & & 0.008 & & 0.029 \\
\hline & 0.029 & 0.005 & 0.013 & 0.001 & 0.048 \\
\hline National Totals & 0.199 & 0.162 & 0.065 & 0.056 & 0.482 \\
\hline
\end{tabular}

It is possible that a different base for CDD pertaining to commercial establishments would have given higher energy savings from commercial cooling, as explained above. During the warm season, restaurants heat indoor air with energy from electrical appliances, and then cool it down again with electrical energy. Residences tend to do the same, as incandescent lights and other appliances are heat sources, although the effect is not nearly as great as in a restaurant.

\subsubsection{Carbon Savings}

Carbon savings by region and for the nation as a whole are summarized in Table 6 . Almost $0.5 \%$ of the nation's carbon emissions could be eliminated by energy-saving thermostat adjustments of $1^{\circ} \mathrm{F}$. Space-conditioning requirements are clearly dominated by heating in the northeast and by cooling in the southeast. The mountain region has large areas in the northern and southern United States so no clear seasonal dominance is evident. The Pacific coast has a mild climate and a low carbon-toelectricity ratio due to reduced coal burning and large hydropower resources. Electricity imports from other regions, which reduce carbon emitted from this region, have been accounted for as explained above. About half of the hydropower in the USA is generated in the 3 states comprising our Pacific region. This leads to a reduced need for hydrocarbon combustion to provide energy. The result is 
lower carbon emissions per capita and less per-capita carbon savings from additional energy conservation measures, as some carbon has already been saved.

Table 6. Annual Carbon Savings (Tg) from a $1^{\circ} \mathrm{F}$ Thermostat Adjustment to Save Energy for 4 regions of the USA.

\begin{tabular}{|c|c|c|c|c|c|}
\hline & \multicolumn{2}{|l|}{ Residential } & \multicolumn{2}{|l|}{ Commercial } & Totals \\
\hline & Heating & Cooling & Heating & Cooling & \\
\hline \multicolumn{6}{|l|}{ Northeast } \\
\hline Electricity & 0.241 & 1.022 & 0.048 & 0.326 & 1.637 \\
\hline Natural Gas & 0.959 & & 0.400 & & 1.359 \\
\hline Fuel Oil & 0.352 & & & & 0.352 \\
\hline Regional Totals & 1.552 & 1.022 & 0.448 & 0.326 & 3.348 \\
\hline \multicolumn{6}{|l|}{ Southeast } \\
\hline Electricity & 0.365 & 1.334 & ns & 0.479 & 2.178 \\
\hline Natural Gas & 0.451 & & 0.193 & & 0.644 \\
\hline Regional Totals & 0.816 & 1.334 & 0.193 & 0.479 & 2.822 \\
\hline \multicolumn{6}{|l|}{ Mountain } \\
\hline Electricity & 0.048 & 0.157 & 0.022 & 0.068 & 0.295 \\
\hline Natural Gas & 0.111 & & 0.068 & & 0.179 \\
\hline Regional Totals & 0.159 & 0.157 & 0.090 & 0.068 & 0.474 \\
\hline \multicolumn{6}{|l|}{ Pacific } \\
\hline Electricity & 0.059 & 0.037 & 0.037 & 0.007 & 0.140 \\
\hline Natural Gas & 0.286 & & 0.111 & & 0.397 \\
\hline Regional Totals & 0.345 & 0.037 & 0.148 & 0.007 & 0.537 \\
\hline National Totals & 2.850 & 2.520 & 0.879 & 0.932 & 7.181 \\
\hline
\end{tabular}

Total carbon savings are over 7 Tg-C annually, which would be enough to offset the carbon emissions of about 1.4 million people. Standard Metropolitan Statistical Areas (SMSAs) with populations of about that number of people include Jacksonville, FL, Memphis, TN-MS-AR, and Louisville/Jefferson County, KY-IN (U.S. Census Bureau, 2012). Any one of these SMASs could have their carbon footprint approximately erased by a $1^{\circ} \mathrm{F}$ thermostat adjustment to save energy. Based on the same sources given in Section 3.3, this could also be expressed as the equivalent of erasing the carbon footprints of 5.7 million automobiles. 


\subsubsection{Monetary Savings}

Table 7 is a summary of monetary savings resulting from a $1^{\circ} \mathrm{F}$ thermostat adjustment to save energy. Savings for a typical individual would be the residential savings divided by the population, or about $\$ 13$ per year. For a typical household, savings would be about 2.58 times that, or a little over $\$ 33$. Savings per person are lowest in the climatically moderate Pacific section. Total annual savings would be about 4 billion dollars for the residential sector, and around 5 billion dollars for both sectors.

Table 7. Annual Monetary Savings (millions of USA dollars) from a $1^{\circ} \mathrm{F}$ Thermostat Adjustment to save Energy for 4 Regions in the USA

\begin{tabular}{|c|c|c|c|c|c|}
\hline & \multicolumn{2}{|l|}{ Residential } & \multicolumn{2}{|l|}{ Commercial } & \multirow[t]{2}{*}{ Totals } \\
\hline & Heating & Cooling & Heating & Cooling & \\
\hline \multicolumn{6}{|l|}{ Northeast } \\
\hline Electricity & 144 & 677 & 26 & 185 & 1,032 \\
\hline Natural Gas & 866 & & 315 & & 1,181 \\
\hline Fuel Oil & 339 & & & & 339 \\
\hline Sectional Totals & 1,349 & 677 & 340 & 185 & 2,551 \\
\hline \multicolumn{6}{|l|}{ Southeast } \\
\hline Electricity & 194 & 779 & ns & 239 & 1,212 \\
\hline Natural Gas & 445 & & 159 & & 604 \\
\hline Sectional Totals & 639 & 779 & 159 & 239 & 1,816 \\
\hline \multicolumn{6}{|l|}{ Mountain } \\
\hline Electricity & 21 & 77 & 7 & 28 & 133 \\
\hline Natural Gas & 95 & & 46 & & 141 \\
\hline Sectional Totals & 115 & 77 & 54 & 28 & 274 \\
\hline \multicolumn{6}{|l|}{ Pacific } \\
\hline Electricity & 71 & 53 & 41 & 9 & 174 \\
\hline Natural Gas & 228 & & 81 & & 309 \\
\hline Sectional Totals & 299 & 53 & 122 & 9 & 483 \\
\hline National Totals & 2,402 & 1,586 & 676 & 461 & 5,124 \\
\hline iffel & 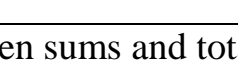 & & & & \\
\hline
\end{tabular}




\section{WATER HEATING}

Much of the electrical energy for lighting and cooking is also inadvertently used for heating, thereby contributing to comfortable conditions during the cold season and adding to the cooling burden in hot months when additional electricity for air conditioning is used to overcome it. Because lighting and cooking for a given calendar month do not change appreciably from one year to the next, our approach of analyzing one calendar month at a time circumvented these difficulties. However, a particularly cold January will require additional electricity for water heating, while the opposite is true for a particularly hot July, when increased space-cooling demand is somewhat compensated by decreased water heating requirements. In the former case, the additional demand for water heating would lead to an increase in energy-use anomaly, which would be falsely attributed to space comfort; in the latter case, the reduced demand for water heating would hide some additional demand for space cooling. In the former case, this would lead to an overestimate of energy savings, in the latter case it would lead to an underestimate.

The problem is further complicated because homes cooled with electric power may have natural gas water heaters, and households heated with natural gas may use electricity for water heating. Because of the complications involved, we present our methodology for dealing with water heating in the appendix.

We investigated the residential sector only, as we were interested in a general impression of water-heating effects; the commercial sector is more complicated to analyze for reasons related to degree-day calculations, as explained above. Additionally, water-heating requirements are often higher for establishments dealing in food or food services, to satisfy local health requirements.

In each of the most populated regions, where estimated energy savings were large, the net corrections resulted in changes of less than one percent of our original national estimates. These small percentages hide much larger seasonal changes, particularly in the southeast where a relatively high percentage of homes use electricity for both space heating and water heating (EIA, 2005a, 2009a). Southeastern energy savings for space heating with electricity was reduced to 89 percent of our originally estimated value while electrical energy for space cooling went up by less than half that percentage. However, the originally calculated energy savings for cooling is a much larger number, so that after estimated savings are recalculated the net correction is a slight increase in our energy savings over the course of a year in the Southeast region. This increase in electrical energy was not completely compensated by the (relatively small percentage) decrease attributable to the use of natural gas for water heating, as relatively few people in the southeast use natural gas for water heating.

The recalculations including water-heating effects reduce the combined net outcome for the northeast and southeast, by less than 1 percent of the originally estimated savings. Calculated energy savings in the sparsely populated mountain region decreased by about 1 percent of our originally estimated value for that region when water heating was considered, while energy savings in the more populated Pacific region was reduced by about 2 percent of our originally estimated values.

The nationally aggregated result of considering water heating was a decrease in our calculated energy savings of less than 1 percent of our originally estimated value except for monetary savings which decreased by 1.6 percent. Ignoring this decrease added a slight high bias to our nationally aggregated estimates. As noted, Regional differences for particular seasons are relatively much larger, and are interesting enough to merit a separate study although for purposes of this exploratory study we did not consider them further. 
(THIS PAGE LEFT BLANK INTENTIONALLY) 


\section{BUT IT'S A DRY HEAT}

Another regional difference that may merit further exploration involves dry vs. humid climates. High humidity leads to water condensation on the fins and coils of air conditioners, adding heat of condensation and inhibiting their cooling effect while removing some moisture from the conditioned space. This additional "latent heat load" results in more electrical energy being needed for a given amount of space cooling, and a correspondingly greater savings for a onedegree thermostat adjustment. We compared savings for residential air conditioning resulting from a $1^{\circ} \mathrm{F}$ upward adjustment in a dry climate, represented by Arizona, and in a humid climate, represented by Florida. Comparison was made for July, when average daily temperatures are about the same in both places and nighttime temperatures seldom dip below $65^{\circ} \mathrm{F}$.

Per capita energy savings in Florida ( $26 \mathrm{~kW}$-h/person- ${ }^{\circ} \mathrm{F}$ ) were estimated as about twice those in Arizona (13 kW-h/person- $\left.{ }^{\circ} \mathrm{F}\right)$. Florida has more carbon emissions per kW-h than Arizona (Rothschild and Diem, 2009), as a higher percentage of its electricity comes from fossil sources (State Electricity Profiles, see Table 1). The overall result is that a $1^{\circ} \mathrm{F}$ thermostat adjustment in Florida would save $4.64 \mathrm{~kg}-\mathrm{C} /$ person- ${ }^{\circ} \mathrm{F}$ for July. This is more than twice the carbon emissions per person as it would in Arizona (1.92 kg-C/ person- $\left.{ }^{\circ} \mathrm{F}\right)$.

Cost per kW-h is also higher in Florida than in Arizona (Table 5.6a of Electric Power Monthly). Therefore, Florida/Arizona monetary savings per $1^{\circ} \mathrm{F}$ thermostat adjustment (\$2.97 vs. \$1.32 per person- ${ }^{\circ} \mathrm{F}$ ) is also greater than the energy-savings ratio.

The above comparison is surely among the extreme contrasts in energy, carbon, and monetary savings among the states, but it demonstrates that the same thermostat adjustment in regions of greatly different relative humidity could lead to a difference in savings that would be a large percentage of the savings at either place. 
(THIS PAGE LEFT BLANK INTENTIONALLY) 


\section{DISCUSSION}

While we believe our approximation is good, this may be partly due to some biases cancelling each other. The use of $65^{\circ} \mathrm{F}$ as a base for degree-days in the commercial sector is almost surely too high. This is already well known in the civil engineering profession, but little documented in the literature. Rosenthal et al. (1995) included an adjustment for this effect in their modeling study. However, our study is empirical, and arbitrary adjustments to data are always risky. The National Climatic Data Center has planned to publish more than one set of CDD totals based on temperatures lower than, as well as equal to, $65^{\circ} \mathrm{F}$ and we encourage this development as soon as possible. The result would be an increase in annual CDD and an increase in variance during months that have zero or a small number of CDD calculated from a $65^{\circ} \mathrm{F}$ base. The increased variance could possibly be related to electricity use. This would increase the savings we calculated, especially in the commercial sector.

Since this research was conducted, the ratio of natural gas to coal as fuel for electricity generation in the USA has increased appreciably. In the first few years of this decade, about $50 \%$ of USA electricity generation was fueled by coal and about $17 \%$ was fueled by gas. It is not unreasonable to assume that what was a 17/50 split will become a 33.5/33.5 split to obtain the $67 \%$ of the USA electrical energy supply provided by carbon-emitting fossil fuels. The effect on carbon emissions would be nontrivial, and is readily calculated from the amount of each type of fuel used and the amount of electrical energy generated from each fuel.

For a given amount of heat energy realized from combustion, natural gas emits only about 0.56 as much oxidized carbon as coal. The higher hydrogen/carbon ratio of natural gas means that more heat energy comes from hydrogen combustion, so less carbon emissions result. For a 33.5/33.5 percentage split between coal and natural gas to obtain $67 \%$ of the USA electrical energy supply, the result is $0.15 \mathrm{~kg}-\mathrm{C} / \mathrm{kW}$-h emitted instead of the 0.175 figure we used. This would reduce our calculated annual carbon savings obtained for electricity in the regional study by about $0.6 \mathrm{Tg}-\mathrm{C}$, or from 7.2 to $6.6 \mathrm{Tg}-\mathrm{C}$, or to about $0.44 \%$ of the overall USA annual carbon emissions from all fossil sources. As noted in Section 3.3, this would be equivalent to erasing the carbon footprint of

over 5 million automobiles, or of over 1.3 million people, which would be about the population of a Standard Metropolitan Statistical Area (SMSA) the size of Louisville/Jefferson County, KY-IN or of Memphis-TN-MS-AR (United States Census Bureau, 2012).

Comparing 2011 with 2001-2010 averages, USA carbon savings from fuel switching were about 17 Tg-C. However, according to EIA (2012b) net USA coal exports in 2011 had increased to their highest level since 1991, and would put about 34 additional Tg-C into the global atmosphere, depending on assumptions one makes about the carbon emitted per unit of heat realized from coal combustion. Natural gas exports added another $10 \mathrm{Tg}$-C. This fuel, imported by other countries, may have led to reductions in their fuel imports from nations other than the USA. However, counting internal use plus exports, the USA contribution to global carbon emissions is still increasing. Additional complications are introduced by the effects of changes in methane emissions resulting from the fracking process to produce additional natural gas. These effects are not yet known; some analyses (e.g., by Wigley, 2011, Petron et al., 2012) suggest that fracking could affect the life cycle of natural gas use so as to make it more effective than coal combustion for increasing the "greenhouse effect." Other studies (e.g. O’Sullivan and Paltsev, 2012) suggest that this may not be the case. 
Our first differencing removed unwanted statistical "noise” associated with corresponding trends in the variables involved. However, it also removed covariance associated with any climatic trends; the result contributes a low bias to our estimated savings of energy, carbon, and money. Additionally, extreme periods of heat typically require additional electrical energy that is "nonbase load" and results in a higher value of carbon emitted per $\mathrm{kW}$-h generated. This also adds a low bias to our carbon-savings estimates. Not including propane and some heating oil in our calculations contributed an additional low bias.

Thermostat adjustments of more than $1^{\circ} \mathrm{F}$ are possible. What we have provided here is a scaling factor, so that a $2^{\circ} \mathrm{F}$ thermostat adjustment would save $7.2 \mathrm{X} 2=14.4 \mathrm{Tg}-\mathrm{C} /$ year, or almost $1 \%$ $(0.96 \%)$ of the nation's annual carbon emissions. This scaling factor would decrease as winter (or summer) climate approaches a comfortable level, so as to require space conditioning for a lesser fraction of the time. 


\section{CONCLUSION}

We believe we have a reasonable scaling factor for estimating the savings in energy, carbon emissions and money that could be achieved by a $1^{\circ} \mathrm{F}$ thermostat adjustment in the residential and commercial sectors of the USA. Such an adjustment would save over 0.4 percent of the primary energy consumed in the USA and a similar percentage of fossil-fuel carbon emissions. More savings would come from heating than from cooling. Although cooling is less efficient from the standpoint of consuming primary energy, space comfort requires more heating than cooling in the climate of the USA. Qualitatively predictable regional variations are present; more energy would be saved in humid regions, as more energy is required to overcome the heat of water condensation, more heating energy is saved in northern regions etc.

If all residential and commercial buildings in the USA had thermostats adjusted by $1^{\circ} \mathrm{F}$, or some combination of adjustments that would have the same effect, the result would be the same as erasing the total carbon footprint of over 1.3 million people. These carbon savings would almost exactly erase the carbon footprint of Jacksonville FL (assuming the average person there has the same carbon footprint as the average U.S. resident). For another comparison, the carbon savings we calculated would be about the same as eliminating over 5 million automobiles. Emissions of other pollutants such as oxides of sulfur and nitrogen would be reduced as well, and a typical American household would save around $\$ 30 /$ year, depending on location. For a $2^{\circ} \mathrm{F}$ thermostat adjustment, the savings would be around $\$ 60 /$ year, etc. 


\section{ACKNOWLEDGEMENTS}

The U.S. Department of Energy Office of Science, Biological and Environmental Research Program, and the Climate Change Science Institute at Oak Ridge National Laboratory supported this work. The Higher Education Research Experience (HERE) program, managed by Oak Ridge Institute for Science and Education (ORISE), Oak Ridge Associated Universities, provided logistical support for the second author. U.T. Battelle, LLC, manages Oak Ridge National Laboratory for the U.S. Department of Energy under Contract DE-AC05-00OR22725. We thank Gregg Marland and Tom Boden for constructive reviews of this manuscript. 


\section{REFERENCES}

Boden, T.A., G. Marland, and R.J. Andres. 2012. Global, Regional, and National Fossil-Fuel $\mathrm{CO}_{2}$ Emissions. Carbon Dioxide Information Analysis Center, Oak Ridge National Laboratory, U.S. Department of Energy. DOI: 10.3334/CDIAC/00001_V2012. Available via: http://cdiac.ornl.gov/trends/emis/meth_reg.html

Boden, T.A., G. Marland, and R.J. Andres. 2012a. Preliminary 2011 Global \& National Estimates by Extrapolation. IN. Carbon Global, Regional, and National Fossil-Fuel $\mathrm{CO}_{2}$ Emissions. Carbon Dioxide Information Analysis Center, Oak Ridge National Laboratory, U. S. Department of Energy. DOI: 10.3334/CDIAC/00001_V2012. Available via: http://cdiac.ornl.gov/trends/emis/meth_reg.html

Davis, S.C., S.W. Diegel and R.G. Boundy. 2012. Transportation Energy Data Book 31. ORNL-6987. Oak Ridge National Laboratory, Oak Ridge, TN.

EIA (Energy Information Administration). 2005. In: Commercial Buildings Energy Consumption Survey--Detailed Tables (E1A) United States Department of Energy. Available via: http://www.eia.doe.gov/emeu/cbecs/cbecs2003/detailed_tables_2003/2003set19/2003pdf/e01a.pdf.

EIA (Energy Information Administration). 2005a. Residential Energy Consumption Survey--Detailed Tables US12, US14 and HC13.8. United States Department of Energy. Available via: http://www.eia.doe.gov/emeu/recs/recs2005/c\&e/detailed_tables2005c\&e.html

EIA (Energy Information Administration). 2006. Energy Consumption by Manufacturers, Table 5.2. United States Department of Energy. Available via: http://www.eia.doe.gov/emeu/mecs/mecs2006/pdf/Table5 2.pdf. Cited 1 Dec 2010.

EIA (Energy Information Administration). 2009. Winter Energy Savings from Lower Thermostat Settings, Release date 12/12/2000, Last modified 04/06/2009. Available via: http://www.eia.gov/emeu/consumptionbriefs/recs/thermostat_settings/thermostat.html

EIA (Energy Information Administration). 2009a. Residential Energy Consumption Survey-Tables HC6.7 and HC8.7 Available via: http://www.eia.gov/consumption/residential/data/2009/

EIA (Energy Information Administration). 2012. Annual Energy Review, published annually by the U.S. Department of Energy, DOE/EIA-384(year). Available via: http://www.eia.doe.gov/aer

EIA (Energy Information Administration). 2012a. State Electricity Profiles Tables 2010. United States Department of Energy. Assistant Administrator for Energy Statistics, Office of Electricity, Renewables, and Uranium Statistics, DOE/EIA-0348(01)/2. Available via: http://www.eia.gov/electricity/state/

EIA (Energy Information Administration). 2012b. Monthly Energy Review, published monthly by the U.S. Department of Energy, DOE/EIA-0035(year/month) DOE/EIA-384(year). Available via: http://www.eia.doe.gov/aer 
EPA (United States Environmental Protection Agency). 2012. Inventory of U.S. Greenhouse Gas Emissions and Sinks 1990-2010. United States Environmental Protection Agency, Annex 2,

EPA (United States Environmental Protection Agency). 2012a. Clean Energy, Calculations and References. Available via: http://www.epa.gov/cleanenergy/energy-resources/refs.html

Hadley, S.W., D.J. Erickson, J. Hernandez, C.T. Broniak, and T.J. Blasing. 2006. Responses of energy use to climate change: A climate modeling study. Geophysical Research Letters 33 L17703

International Code Council. 2003. International Energy Conservation Code, Section 302 Thermal Design Parameters; 302.1 Exterior design conditions. Available via: http://resourcecenter.pnl.gov/cocoon/morf/ResourceCenter/article/1468?display=print

Lucas, R., P. Fairey, R. Garcia, M. Lubliner. 2007. National Energy Savings Potential in HUD-Code Housing from Thermal Envelope and HVAC Equipment Improvements. Paper LB-07-006, National meeting of the American Society of Heating, Refrigeration and Air-Conditioning Engineers (ASHRAE), ASHRAE Transactions 113, Part 2. Available via: https://www.energycodes.gov/status/documents/HUDcodeASHRAE_June.pdf

O’Sullivan, F., and S. Paltsev. 2012. Shale gas production: potential versus actual greenhouse gas emissions. Environmental Research Letters 7 044030. DOE: 10.1088/1748-93267/4/044030.

Pacala, S., R. Socolow. 2004. Stabilization Wedges: Solving the Climate Problem for the next 50 years with Current Technologies. Science, 305 (5686):968-972.

Petron, G., G. Frost, B. R. Miller, et al. 2012. Hydrocarbon emissions characterization in the Colorado Front Range: A pilot study. Journal of Geophysical Research: Atmospheres 117. DOI: 10.1029/2011JD016360.

Rosenthal, D.H., H.K. Gruenspecht, E. Moran. 1995. Effects of Global Warming on Energy Use for Space Heating and Cooling in the United States. The Energy Journal 16 (2):77-96.

Rothschild, S., A. Diem. 2009. Total, Non-base load, eGRID Subregion, State. Guidance on the Use of eGRID Output Emission Rates. Paper presented at the U.S. Environmental Protection Agency Emission Inventory Conference. Baltimore, Maryland. May 2009. Available via: http://www.epa.gov/ttn/chief/conference/ei18/session5/rothschild.pdf

Rothschild, S., A. Diem, C. Quiroz, M. Salhotra. 2010. The Value of eGRID and eGRIDweb to GHG Inventories. Paper presented at the Energy, Utility and Environmental Conference.

Phoenix, AZ. February 2010. Available via:

http://www.epa.gov/cleanenergy/documents/egridzips/The_Value_of_eGRID_Dec_2009.pdf

Torcellini, P., S. Pless, M. Deru, D. Crawley. 2006. Zero Energy Buildings: A Critical Look at the Definition. Paper NREL/CP-550-39833, presented at the American Council for an Energy Efficient Economy Summer Study: 14-18 August 2006. Pacific Grove, California. 2006:1-10.

Vose. R. (Director, Product Development Branch, National Climatic Data Center): personal communication to T.J. Blasing, July 23, 2010. 
United States Census Bureau, Population Division. 2012. Annual Estimates of the Population of Metropolitan and Micropolitan Statistical Areas: April 1, 2010 to July 1, 2011. (CBSA-EST2011-01) Available via: http://www.census.gov/

Wigley, T.M.L. 2011. Coal to gas: the influence of methane leakage. Climatic Change (2011) 108:601-608. DOI 10.1007/s10584-011-0217-3. 
(THIS PAGE LEFT BLANK INTENTIONALLY) 


\section{APPENDIX}

\section{Effects of water heating}

Variations in energy used for water heating depend primarily on the desired temperature $T_{d}$, to which the water is heated and the water temperatures in the main lines, or "mains" which have an annual range of about $10-12^{\circ} \mathrm{C}$ (Burch and Christensen, 2007). We assumed that values ranged from $4^{\circ} \mathrm{C}$ in winter to $16^{\circ}$ in summer (more precisely, 40 to $60^{\circ} \mathrm{F}$ ) in the northern census divisions and from $16^{\circ}$ to $27^{\circ}$ (more precisely $60-80^{\circ} \mathrm{F}$ ) in the southern divisions. This is roughly $0.4(0.6)$ times the annual temperature range in the north (south). Next, we estimated the standard deviation of the mains water temperatures as 0.4 times the standard deviation of the air temperature for a particular calendar month in the Northeast region, 0.6 in the Southeast and Pacific regions, and 0.5 in the Mountain region. Note that the fraction of the air-temperature variation is lower in the north where the mains must be buried deeper to avoid freezing.

For numerical calculations, we used January as a typical winter month and July as a typical summer month. These months are actually biased toward extremes; the standard deviation of a typical winter month is actually lower than January and the standard deviation of a typical summer month is actually greater than July. The net effect of these assumptions is to bias our heating corrections high and our cooling corrections low, so that overall we may be overcorrecting somewhat. However, these biases are all very slight.

From Table WH6 of the 2005 Residential Energy Consumption Survey (EIA, 2009) we may obtain a reasonably accurate measure of the total annual energy $\left(E_{a n}\right)$, and average monthly energy $\left(E_{m a}=\right.$ $E_{a n} / 12$ ) necessary to heat water to a desired temperature $T_{d}$.

We then estimate the energy required $\left(E_{w}\right)$ to increase the winter water temperature in the mains, $T_{w}$, to the desired hot water temperature, $T_{d}$, as proportional to the difference between $T_{d}$ and $T_{w}$.

$$
\mathrm{E}_{\mathrm{w}}=\mathrm{E}_{\mathrm{ma}} \cdot\left(\mathrm{E}_{\mathrm{w}} / \mathrm{E}_{\mathrm{ma}}\right)=\mathrm{E}_{\mathrm{ma}} \cdot\left(\mathrm{T}_{\mathrm{d}}-\mathrm{T}_{\mathrm{w}}\right) /\left(\mathrm{T}_{\mathrm{d}}-\mathrm{T}_{\mathrm{an}}\right)
$$

where $T_{\text {an }}$ is the annual average water temperature in the mains. Similarly, to obtain an estimate of the average energy required for water heating in summer, $\mathrm{E}_{\mathrm{s}}$ :

$$
E_{\mathrm{s}}=\mathrm{E}_{\mathrm{ma}} \cdot\left(\mathrm{T}_{\mathrm{d}}-\mathrm{T}_{\mathrm{s}}\right) /\left(\mathrm{T}_{\mathrm{d}}-\mathrm{T}_{\mathrm{an}}\right)
$$

where $T_{s}$ is the average summer temperature in the mains.

A winter (or summer) with mains water temperatures of one standard deviation below (or above) the mean would then require a standard deviation more $\mathrm{E}_{\mathrm{w}}+\sigma \mathrm{E}_{\mathrm{w}}$, (or less, $\mathrm{E}_{\mathrm{s}}-\sigma \mathrm{E}_{\mathrm{s}}$ ) energy.

$$
\begin{aligned}
& \sigma \mathrm{E}_{\mathrm{w}}=\mathrm{E}_{\mathrm{w}} \cdot\left(\mathrm{T}_{\mathrm{d}}-\mathrm{T}_{\mathrm{w}}+\sigma \mathrm{T}_{\mathrm{w}}\right) /\left(\mathrm{T}_{\mathrm{d}}-\mathrm{T}_{\mathrm{w}}\right)-\mathrm{E}_{\mathrm{w}} \\
& \sigma \mathrm{E}_{\mathrm{s}}=\mathrm{E}_{\mathrm{s}} \cdot\left(\mathrm{T}_{\mathrm{d}}-\mathrm{T}_{\mathrm{s}}-\sigma \mathrm{T}_{\mathrm{s}}\right) /\left(\mathrm{T}_{\mathrm{d}}-\mathrm{T}_{\mathrm{s}}\right)-\mathrm{E}_{\mathrm{s}}
\end{aligned}
$$

The estimated standard deviation of energy use (electric, gas, or oil) for water heating was then weighted by the decimal fraction of households using each respective energy source for each region, to arrive at an adjusted standard deviation for water heating, $\sigma(w h)_{\text {adj. }}$ Because the thermally driven variance was taken to be from space conditioning plus water heating, the total thermally driven 
variance in energy consumption, $\mathrm{V}(\mathrm{T})$, is the total variance in energy consumption, $\mathrm{V}$, times the variance in common with the degree-day variable:

$$
\mathrm{V}(\mathrm{T})=\mathrm{V} \cdot\left(\mathrm{R}^{2}\right)=\sigma(\mathrm{wh})_{\mathrm{adj}}^{2} \pm 2 \sigma(\mathrm{wh})_{\mathrm{adj}} \cdot \sigma(\mathrm{sc})+\sigma(\mathrm{sc})
$$

where $\sigma(\mathrm{sc})$ is the standard deviation of the energy consumed for space conditioning. The standard deviation of the total energy consumed for a month is

$$
\sigma \mathrm{R}=\sigma(\mathrm{wh})_{\mathrm{adj}} \pm \sigma(\mathrm{sc})
$$

So that a typical departure would consist of a standard deviation due to water heating and a standard deviation due to space conditioning.

The fraction attributable to space conditioning would then be:

$$
\sigma(\mathrm{sc}) / \sigma \mathrm{R}
$$

Each calculated energy savings, carbon savings and dollar savings terms were multiplied by the fraction attributed to space heating (note that this would exceed 1.0 for CDD). As noted in the text, large corrections for the heating season tended to cancel large corrections for the cooling season, and the corrections involved varied by region.

The commercial sector was not investigated here; this exercise was simply to estimate the magnitude of corrections for water heating. In restaurants, for example, health regulations frequently require much higher water temperatures than many people have at home. Also, kitchen heat has to be offset for summer space conditioning, so that energy requirements increase for two reasons. In winter, kitchen heat reduces the energy need for space conditioning, but additional energy is required for water heating. These considerations can be better investigated after a more proper formulation of degree-days is established for commercial establishments.

\section{REFERENCES}

EIA, 2009. 2005 Residential Energy Consumption Survey--Detailed Tables, available online at: http://www.eia.doe.gov/emeu/recs/recs2005/c\&e/detailed_tables2005c\&e.html

Burch, J., and Christensen, C. 2007. "Towards Development of an Algorithm for Mains Water Temperature.” Proceedings of the 2007 ASES Annual Conference, Cleveland, OH. 